\title{
'It's not about lawyers, it's about the protection of the most vulnerable in our society'
}

Thanks to Young Legal Aid Lawyers for the poster on the back page. See their regular column on page 11. Their website: www.young legalaidlawyers.org

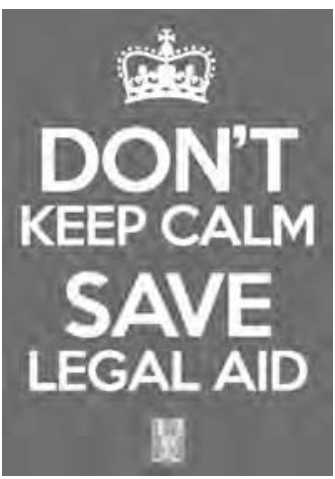

On 2nd May 2013 a perhaps little noticed comment piece appeared in the pages of The Financial Times entitled: 'Austerity is not the only answer to a debt problem'. The article was co-written by the Harvard University professors Kenneth Rogoff and Carmen Reinhart, seen by many to be the intellectual authors of the austerity measures that have been and continue to be rolled out across the UK and Europe. This revealing article appeared following a strong debate on the efficacy of austerity as a means of dealing with the current financial crisis after an economics student, also at Harvard, found out almost by accident that the data and figures that had been compiled to support Rogoff and Reinhart's theories did not stack up. The shortcomings in the austerity narrative have been highlighted yet again more recently by the International Monetary Fund's admission on 5th June 2013 that it had failed to realise the damage austerity would do to Greece. In this issue Jeremy Smith analyses the attempts at subversion of European constitutions in the name of austerity.

Much of this issue of Socialist Lawyer is dedicated to the ongoing campaign against the further round of cuts being proposed to legal aid, coming hard on the heels of the cuts already introduced by the Legal Aid Sentencing and Punishment of Offenders Act 2012 which came into force on 1st April 2013. The deficiencies inherent in arguments put forward in favour of austerity should be at the forefront of the mind when considering the coalition Government's continued ideological pursuit of the destruction of legal aid. The campaign is not about lawyers and their remuneration but about the protection of the most vulnerable in our society and the preservation of an essential pillar of the welfare state.

The good news is that large parts of the profession have united against the proposals for further cuts to legal aid. 13,000 responses were sent to the Ministry of Justice's consultation Transforming Legal Aid:Delivering a more credible and efficient system which closed on 4th June 2013. Crown Court judges have come out against the proposals. A large number of Treasury counsel have sent in a joint response in opposition to the proposals. Among their reservations, they express particular concerns about the proposals to introduce a residence test for civil legal aid which 'risks creating an underclass of persons within the UK for whom access to the courts is impossible'. They go on to state that 'To deny legal aid altogether to such persons, so that even the minimal rights provided to them by the law cannot be enforced, is in our view unconscionable.' Strong words from the Government's own lawyers.

There have been unprecedented and strongly attended demonstrations by lawyers both outside Parliament on 22nd May 2013 and outside the Ministry of Justice (MOJ) on 4th June 2013. The latter of these two protests was sufficiently well attended to lead to the spontaneous closure of Petty France, the road outside the MOJ. The hope is that the unity and momentum which has been invoked across the profession in opposition to these ill considered proposals continues. The consultation may have closed on 4th June 2013 but many battles lie ahead for the campaign as the Government's proposals look set to be put before Parliament later this year.

The Haldane Society's President, Michael Mansfield QC, issues a rallying cry to the campaign in this issue while Anna Morris asks: at what price justice? This is a particularly pertinent question as the Lord Chancellor Chris Grayling has set his sights not only on cutting back legal aid but also on privatising both the Probation Service and the Court Service. Within the context of the campaign to save legal aid it is helpful that campaigns such as those being run by UK Uncut continue to remind our politicians and media of the scandal of massive tax avoidance. The estimated $£ 4.5$ billion UK Uncut says there is in unclaimed tax is a staggering amount to bear in mind as the Government seeks to continue to justify its deconstruction of the welfare state.

While the campaign in the UK to save publicly funded justice continues, contained within this issue are a number of accounts from other legal campaigns across the world. There is focus on the groundbreaking trial and conviction of Guatemala's former dictator Efrain Ríos Montt for genocide, and the subsequent decision of Guatemala's Constitutional Court to overturn the conviction and remit the case for a retrial. Siobhán Lloyd recalls her time spent working in Guatemala City for the legal centre Centro para la Acción Legal en Derechos Humanos. Also in Central America, the legal academic Camilo Pérez-Bustillo writes about the upcoming hearings being scheduled to take place in Mexico City as part of the Permanent Peoples' Tribunal with the aim of shining a light on the oft forgotten violent story of migrants making their way from Latin America to the USA.

Tim Potter, editor (socialistlawyer@haldane.org) 